\title{
What can Eastern European countries learn from the Slovak economy? A twin
} deficit growth approach.

\begin{abstract}
This paper applies an extended growth model to the Slovak economy and explains the potential pitfalls that a transition economy faces on the way to converging with other advanced European countries. Our empirical analysis shows that Slovakia grew at a higher rate than that allowed by the balance-of-payments equilibrium rate and that this is consistent with the accumulation of trade deficits over time. A scenarios analysis shows that improving trade competitiveness, changing import and export shares toward a current account balance, and financing the economy at a lower cost will be the most successful ways to achieve higher growth.
\end{abstract}

JEL code: $\mathrm{C} 32, \mathrm{E} 12, \mathrm{H} 6, \mathrm{O} 4$

Keywords: internal and external imbalances, price and income elasticities of trade, equilibrium growth rates, 3SLS system regressions, supply constraints.

Author for correspondence: Elias Soukiazis, Faculty of Economics, University of Coimbra, Av. Dias da Silva, 165, 3004-512 Coimbra, Portugal, e-mail: elias@fe.uc.pt. 


\section{Introduction}

The balance-of-payments constrained growth hypothesis was first introduced by Thirlwall (1979). Using a simple demand oriented approach, he established the so-called growth rate consistent with the balance-of-payments equilibrium. This hypothesis defines a simple regularity (known as Thirlwall's Law) that actual growth can be approximately predicted by the ratio of export growth to the income elasticity of import demand or, alternatively, by the product of the ratio of the income elasticity of exports to that of imports and the growth rate of foreign income. More specifically, the first regularity is given by $\dot{y}=\frac{\dot{x}}{\pi}$ and the alternative one by $\dot{y}=\frac{\varepsilon}{\pi} \dot{y}^{*}$, where $\dot{y}$ is the growth of domestic income, $\dot{y}^{*}$ the growth of foreign income (rest of the world), $\dot{x}$ the growth of real exports, $\pi$ the income elasticity of import demand and $\varepsilon$ the income elasticity of export demand. To derive these simple relations, relative prices are assumed to be constant and the balance-of-payments is in equilibrium (on the current account) ${ }^{1}$. The implication of Thirlwall's Law is that no country can grow faster than its balance-ofpayments equilibrium growth rate, unless it can continuously finance external deficits by capital inflows, which is not always a sustainable solution ${ }^{2}$. Growth is constrained by external demand and the balance-of-payments disequilibrium on the current account (external imbalance) can be a serious impediment to higher growth when it cannot be financed by the available foreign resources. Another crucial implication of the model is that it is income and not relative prices that adjusts to bring the economy into equilibrium. For this reason, international relative prices are not playing a significant role (are neutral) in long-term analyses.

Numerous empirical studies have tested the validity of Thirlwall's Law or criticized the basic assumptions that it relies on, namely that relative prices are constant in the long-run and that the current account is initially balanced. Among others, McCombie (1989), Moreno-Brid (1998-

\footnotetext{
${ }^{1}$ For recent applications of Thirlwall's Law, see Soukiazis and Antunes (2012) regarding Portugal and Soukiazis et al (2013) regarding the Slovak Republic.

${ }^{2}$ Financing the current account with capital inflows is not a sustainable solution in the long-run and does not have the same dynamic effects on growth as the export-led policy.
} 
99), McCombie and Thirlwall (1994) and recently Blecker (2009) have made valuable contributions discussing and criticizing the underlying implications of the Law.

The hypothesis of constant relative prices has been widely criticized in the empirical literature (e.g. McGregor and Swales, 1985; 1991; Alonso and Garcimartín, 1998-99; López and Cruz, 2000). In most studies in this area, however, relative prices have shown to be statistically insignificant, and when they are significant, the price elasticities of imports and exports are very low when compared to income elasticities. This reveals that imports and exports react less to price changes (are inelastic) in comparison to income changes (are elastic). Blecker (2009) stressed that the longer the time period considered, the more likely it is that relative prices remain constant. Evidence provided by empirical literature seems to support the idea that income is the variable that adjusts to equilibrate external imbalances, implying therefore that growth is indeed balance-of-payments constrained. On the other hand, increasing capital inflows can, at most, temporarily relax the balance-of-payments constraint, but this is not a long-term solution since capital inflows do not allow a country to grow at the export-led cumulative growth rate. What matters in a long-term analysis is the growth of real exports, which have higher multiplier effects on domestic income.

Although Thirlwall's model has been modified to include capital flows and foreign debt, these studies have not considered the role of public imbalances caused by public deficit and debt as additional constraints to growth. The recent experience of some peripheral euro zone countries falling into a public debt trap (Greece, Ireland, Portugal, Spain, Italy and recently, Cyprus) is the motivation for dealing with this issue. As it is known, the implementation of an expansionary fiscal policy, aiming to achieve higher growth and reduce unemployment, does not always achieve the desired objectives (Pelagidis and Desli, 2004). It could be that budget deficits financed either by money printing or by public borrowing ultimately increase public debt and interest rates, crowd out private investment, aggravate inflation or harm medium-term growth. The issue of whether budget deficits are always desirable has many dimensions, including whether government borrowing is used to finance government consumption or 
investment in infrastructure, whether the deficit is sustainable, and how it is financed. On the other hand, the hesitation of many policy makers - especially in Europe - to rely more aggressively on fiscal policy measures to keep their public finances balanced may lead to a vicious cycle of low growth or economic stagnation. The recent austerity programs implemented in some peripheral countries (Greece and Portugal) confirm this reality.

Our paper aims to contribute to this debate by using a more complete growth model, in the spirit of Thirlwall's Law, that considers not only external but also internal imbalances that emerge from trade and fiscal deficits (the twin deficit hypothesis). The model also relaxes the controversial assumption of the neutrality of relative prices by assuming they can play a significant role in the pace of economic growth. Our model was previously applied to Portugal and Italy, revealing that it is very coherent in identifying the most important determinants of growth, mainly associated with trade competitiveness. It has also been shown that factors related to fiscal policy and public finances (internal imbalances) significantly influence the pace of economic growth in these countries. Our present interest is to test our model on a new euro zone member - Slovakia - and assess the expected economic performance of this country. Slovakia is a special case study, belonging to the group of transition economies and displaying encouraging results in economic improvement and integration in the market economy after its separation from the former Czechoslovakia in 1993.

Since 1993, Slovakia has experienced dynamic growth for over twenty years. Over the period of 1994-2015, the country grew at an average rate of $4.19 \%$, higher than that of the Czech Republic (2.65\%) and the EU12 (1.54\%). This economic growth is the result of the catching-up process and favorable world economic conditions prior to the financial crisis. Structural funds coming from the EU and foreign direct investment contributed significantly to the improvement of basic infrastructures. Domestic consumption, and particularly foreign demand, contributed to steady economic growth, while manufacturing and construction have been the fastest growing sectors. 
The Slovak economy is one of the most open economies, with a degree of openness achieving $180 \%$, followed by Hungary (171\%), the Czech Republic (160\%) and the Baltic countries (145\% on average). Its exports mostly consist of products from the high and medium tech sectors, such as vehicles $(27 \%)$, electronics $(21 \%)$, machinery and equipment $(12 \%)$, iron and steel (4\%) and mineral fuels (4\%). EU countries are traditionally the most important export destination markets, absorbing $85 \%$ of Slovakia's total exports with Germany in first place (22.4\%), followed by the Czech Republic (12.4\%), Poland (8.3\%) and Austria (6.0\%). In addition, imports also grew at a dynamic rate, representing mostly import-intensive investment goods.

The relative growth success of Slovakia lies in a pro-active policy of structural changes in the economy, which began shortly before its accession to the EU and culminated with the adoption of the Euro in 2009. Nevertheless, greater economic growth in Slovakia was often associated with internal and external imbalances, which have resulted in a relatively high unemployment rate and a high current account deficit. Taking all these characteristics into consideration, the Slovak economy is an interesting case study among the transition economies for identifying the shortcomings of its relative growth success.

To this end, this paper is organized as follows: in Section 2, we briefly present the extended growth model that takes internal and external imbalances into account and assumes that relative prices are not neutral; Section 3 estimates the structural equations of the model; Section 4 tests the model for the Slovak economy to identify the main determinants of growth; a scenario analysis is provided in Section 5, focusing on the factors that could foster or harm economic growth in Slovakia; and finally, Section 6 presents the main conclusions and policy recommendations that could help the country further improve its economic performance.

\section{Modeling the determinants of growth.}

Soukiazis et al. (2013-14) developed a multi equation model where income growth in the domestic economy depends, among other things, on internal and external imbalances, and 
relative prices are assumed to play a non-idle role. This approach is in line with the balance-ofpayments constrained growth hypothesis first developed by Thirlwall (1979), which became known as Thirlwall's Law ${ }^{3}$. Our model is an extended version of Thirlwall's Law, having specific differences: (i) in addition to external imbalances (in the current account), it introduces internal imbalances (emerging from public deficit and debt) as determinants of growth; it considers the sensitivity of imports in relation to changes in the components of domestic income rather than changes in aggregate income, as in Thirlwall's model; relative prices ${ }^{4}$ are introduced explicitly into the growth model through the import and export functions; financial factors, such as interest rates paid to serve public debt and the share of home and foreign bond holders, are considered additional determinants of growth; the structural equations of the system are estimated jointly by 3SLS, the most efficient estimation method that considers the interrelations between the core variables of the system.

The extended growth model encompasses the following equations, which must be estimated simultaneously ${ }^{5}$ :

$\dot{m}=\pi_{c} \dot{c}+\pi_{g} \dot{g}+\pi_{x} \dot{x}+\pi_{k} i \dot{n} v+\delta_{m}\left(\dot{p}^{*}+\dot{e}-\dot{p}\right) \quad$ Imports

$\dot{x}=\varepsilon_{x} \dot{y}^{*}+\delta_{x}\left(\dot{p}^{*}+\dot{e}-\dot{p}\right)$ Exports

$\dot{c}=\varepsilon_{c} \dot{y}_{d}$ Private consumption

$i \dot{n} v=\varepsilon_{K} \dot{y}+\varepsilon_{r} \dot{r}$

Private investment

\footnotetext{
${ }^{3}$ For a detailed discussion on the history and new developments of this Law, see Soukiazis and Cerqueira (2012).

${ }^{4}$ The original Thirlwall's Law assumes that relative prices remain constant in long-term analysis, but this assumption is debatable, used in some studies for the sake of simplification. Many studies have shown that relative prices are important for international trade and explain a substantial part of economic growth. As an example, Garcimartín et al. (2010-11) attributed the slowdown of economic growth in Portugal to the adoption of a strong currency (loss of price competitiveness) when this country joined the euro zone.

${ }^{5}$ The time index $t$ is not attached to the variables for the sake of simplification. Appendix A provides full information on the variables used in the system and the data source.
} 
The first equation of the system explains the growth of imports $\dot{m}$ in function of the growth of demand components such as the growth rates of private consumption $\dot{c}$, primary government expenditures $\dot{g}$, exports $\dot{x}$, and investment $i \ddot{v} v$, respectively. The growth of imports is also assumed to depend on the growth rate of relative prices, given by $\left(\dot{p}^{*}+\dot{e}-\dot{p}\right)$ where $\dot{p}$ and $\dot{p}^{*}$ are the growth rates of domestic and foreign prices respectively, and $\dot{e}$ the variation of the exchange rate over time ${ }^{6}$. In the same equation, $\pi$ represents the elasticity of imports with respect to each of the components of demand, which are all expected to be positive since all components of demand have import content. In addition, $\delta_{m}<0$ is the relative price elasticity of import demand with an expected negative sign, indicating that currency devaluation is expected to reduce import demand by making them more expensive in the domestic market.

Equation (2) explains export growth performance $\dot{x}$ as mainly a function of foreign income growth $\dot{y}^{*}$ (external demand) and the growth of relative prices as defined in the import equation. It is therefore explicitly assumed that export competitiveness is based on price and non-price competitiveness captured by the price and income elasticity of export demand. Specifically, $\varepsilon_{x}>0$ is the income elasticity of export demand, capturing the non-price characteristics of exportable goods such as quality, design, reliability, varieties, etc. In the same equation, $\delta_{x}>0$ represents the relative price elasticity of export demand with an expected positive sign, indicating that currency depreciation reduces the price of exports in international markets, thereby increasing their demand.

Aggregate consumption is mainly a function of the total disposable income (which includes returns obtained from holding government bonds) given by Equation (3), where $\dot{c}$ is the growth of private consumption, $\dot{y}_{d}$ the growth of disposable income and $\varepsilon_{c}>0$ the income elasticity of consumption.

${ }^{6}$ Exchange rate is defined as the domestic price of foreign currency. Therefore, an increase in $e$ indicates depreciation of the domestic currency. 
Private investment is specified according to the conventional accelerator theory ${ }^{7}$, stating that the growth of gross investment $i \dot{n} v$ is a function of the growth of domestic income $\dot{y}$ and the real interest rate $\dot{r}$ as shown in Equation (4). In this equation, $\varepsilon_{k}>0$ is the accelerator effect and $\varepsilon_{r}$ $<0$ reflects the impact of real cost in financing gross investment.

The growth model further includes the government sector, assuming that the government budget (in nominal terms) is given by the following identity:

$$
G_{n}+i B_{H}+i * B_{F} e=t Y P+D
$$

where $G_{n}$ stands for nominal primary government expenditures, $B_{H}$ is public debt $^{8}$ owned by home bond holders, $B_{F}$ is public debt owned by foreign bond holders, $Y$ is domestic income, $P$ is the domestic price level, $D$ the public deficit, $i$ and $i^{*}$ are nominal interest rates paid to home and foreign public debt holders, respectively, $e$ the nominal exchange rate, and $t$ is the tax rate on nominal income. Equation (5) allows us to define the alternative expression $G_{n}+i B_{H}+i * B_{F} e>t Y F$, which shows that public deficit exists when total current expenditures (including interest payments on public debt) exceed revenues obtained through taxes on domestic money income.

The long-term relationship of the growth of real primary government expenditures $\dot{g}$ is given by 9 :

$$
\dot{g}=\frac{t \dot{y}}{w_{G}}+(\dot{d}-\dot{p}) \frac{w_{D}}{w_{G}}-\left[\Delta i+i\left(\dot{b}_{H}-\dot{p}\right)\right] \frac{w_{B H}}{w_{G}}-\left[\left(e \Delta i^{*}+i * \Delta e\right)+i * e\left(\dot{b}_{F}-\dot{p}\right)\right] \frac{w_{B F}}{w_{G}}
$$

\footnotetext{
${ }^{7}$ For more details on the original specification of the investment function see Goodwin (1951) and Chenery (1952).

${ }^{8}$ Public debt is originated by issuing government bonds to finance budget deficit.

${ }^{9}$ In order to avoid replications we do not present the full development of the extended model. More details for the derivations can be found in Soukiazis et al. (2012) (see Appendix A, Equation A.5).
} 
where $w_{D}=\frac{D}{Y P}$ is the budget deficit ratio, $w_{G}=\frac{G}{Y P}$ is the primary government expenditure ratio, $w_{B H}=\frac{B_{H}}{P Y}$ and $w_{B F}=\frac{B_{F}}{P Y}$ are the shares of public debt owned by home and foreign bond holders (as a percentage of nominal income), respectively, $\dot{d}$ is the growth of budget deficit and $\dot{b}_{H}$ and $\dot{b}_{F}$ are the growth rates of public debt owned by home and foreign bond holders, respectively.

The last relation to complete the growth model is an external balance condition given by the following identity:

$$
X P+D_{F} e-i * B_{F} e=M P * e
$$

The left-hand side of the identity shows the money resources available to finance imports consisting of export revenues $X P$ and public deficit assets held by foreigners $D_{F} e$, less interest rate payments on foreign bond holders $i * B_{F}$. As shown in Soukiazis et al. (2012) (see Appendix $B$, Equation (B.6)) the final balance of payments relation can be expressed as:

$$
\dot{x}+\dot{p}+(1-\xi) \frac{w_{D}}{w_{X}}\left(\dot{p}+\dot{y}-i^{*}\right)-(1-\xi) \frac{w_{B}}{w_{X}} \Delta i^{*}=\frac{w_{M}}{w_{X}} \frac{P^{*} e}{P}\left(\dot{m}+\dot{p}^{*}+\dot{e}\right)(\mathbf{8})
$$

where $\dot{x}, \dot{m}, \dot{p}, \dot{p}^{*}, \dot{y}$ and $\dot{e}$ are the growth rates of exports, imports, domestic prices, foreign prices, domestic income and nominal exchange rates, respectively. Additionally, $w_{D}, w_{B}, w_{M}$ and $w_{X}$ are the ratios of budget deficit, public debt, imports and exports to income, respectively. Finally, $(1-\xi)$ represents the percentage of public deficit (or debt) owned by foreign bond holders.

In an explicit manner, Soukiazis et al. (2012) (see Appendix C, Equation (C.4)) show that the growth rate of domestic income can be given by the following relation:

$\dot{y}_{a}=\frac{A}{B}$ 
where

$$
A=\left[\begin{array}{l}
\left(\begin{array}{l}
\left.\varepsilon_{x}-\frac{w_{M}}{w_{X}}\left(\frac{P^{*} e}{P}\right) \pi_{x} \varepsilon_{x}\right) \dot{y}^{*}+\left(\delta_{x}\left(1-\frac{P^{*} e}{P} \frac{w_{M}}{w_{X}} \pi_{x}\right)-\delta_{m} \frac{w_{M}}{w_{X}}\left(\frac{P^{*} e}{P}\right)\right)\left(\dot{p}^{*}+\dot{e}-\dot{p}\right)+ \\
+\left(\dot{p}-\frac{P^{*} e}{P} \frac{w_{M}}{w_{X}}\left(\dot{p}^{*}+\dot{e}\right)\right)+(1-\xi) \frac{w_{D}}{w_{X}}\left(\dot{p}-i^{*}\right)-(1-\xi) \frac{w_{B}}{w_{X}} \Delta i^{*}- \\
-\left(\frac{P^{*} e}{P}\right) \frac{w_{M}}{w_{X}}\left\{\begin{array}{l}
(1-t)+r \xi w_{B} \\
+\pi_{g}\left[-\Delta i \frac{\xi w_{B}}{w_{G}}-\Delta i^{*} e(1-\xi) \frac{w_{B}}{w_{G}}\right]
\end{array}\right.
\end{array}\right\}
\end{array}\right]
$$

and

$$
\begin{aligned}
& B=\frac{w_{M}}{w_{X}}\left(\frac{P * e}{P}\right)\left\{\pi_{c} \varepsilon_{c}+\pi_{k} \varepsilon_{k}+\pi_{g}\left(\frac{t}{w_{G}}+\frac{w_{D}}{w_{G}}-\frac{i \xi w_{B}}{w_{G}}-i * e(1-\xi) \frac{w_{B}}{w_{G}}\right)\right\}- \\
& -(1-\xi) \frac{w_{D}}{w_{X}}
\end{aligned}
$$

Equation (9) is a more complete form of a vast number of determinants that can affect economic growth. Among other factors, the growth of domestic income is determined by internal and external imbalances, which was our initial task, but also considers the effect of relative prices. Namely, the numerator A is decomposed into various parts: the first part measures the impact of foreign demand $\dot{y}^{*}$ on domestic growth through the income elasticity of export demand $\varepsilon_{x}$; the second and third terms capture the effect of relative prices on growth through the price elasticities of exports and imports $\delta_{x}$ and $\delta_{m}$, respectively; the fourth and fifth elements capture the effects of budget deficit and debt on growth as well the cost of financing internal imbalances; the last term is the volume effect of trade through the ratio of import to export shares $w_{m} / w_{x}$. The denominator mostly captures the effect of the disaggregated import elasticities of demand components on domestic growth. Equation (9) will be used to explain actual growth in Slovakia. 


\section{Estimation of the structural equations}

To apply the extended model to the Slovak economy, we first need to simultaneously estimate Equations (1) to (4) to obtain the elasticities needed to compute the reduced form of the domestic income growth as defined in Equation (9). Annual data (growth rates) are used for the 1996-2015period to estimate the system of four equations. Variable definitions and data sources are explained in Appendix A. The method used for estimating the system equations is 3SLS (Three-Stage Least Squares), the most efficient method of capturing the interrelations between equations and the causal and feedback effects between the core variables of the system. Table B.1 in Appendix B presents the estimation results where the endogeneity of regressors is controlled by using a set of instrumental variables. The growth of imports, consumption, investment, and exports are assumed to be endogenous, as is the growth of primary government expenditures, domestic disposable income, domestic product, real exchange rate and real domestic interest rate. The choice of endogenous variables is based on the definition of the structural equations in the system and the reciprocal interrelation between the dependent variables and the regressors supported by economic theory and policy orientation. All other variables in the system are assumed exogenous, including some lagged variables, as explained in the same table. The selection of the exogenous variables and instruments is controlled by the diagnostic tests reported in Table B.2 (Sargan test), which confirm their validity.

In general, the estimation results are quite satisfactory ${ }^{10}$. In the import equation, export growth is the most statistically significant variable at the $1 \%$ level, giving evidence that, other things held constant, each 1 percentage point increase in exports is associated with a 0.791 percentage point increase in imports. This high sensitivity of imports to exports can be a drawback for the Slovak economy in terms of the multiplier effect that exports are expected to have on economic growth. The positive effects of exports on growth can be crowded out by the high dependence of exports on imports. Investment growth and government spending growth are also statistically

\footnotetext{
${ }^{10}$ It was not possible to use a longer period due to lack of data, given that official series for Slovakia begin in 1993 (the year of the division of the former Czechoslovakia into the Czech Republic and the Slovak Republic). Therefore, the robustness of the estimation results must be interpreted with caution.
} 
significant in the import function at the 5\% significance level, but the import sensitivity of these demand components is lower than that of exports. We do not find any significant impact of consumption growth on import growth, an unexpected result despite elasticity carrying the correct sign and being sizable. Relative prices also display a non-significant impact on imports, confirming the standard evidence in the literature that imports are more sensitive to changes in demand elements than to price changes.

In the export function, our results confirm the standard literature findings that exports are income elastic and price inelastic. The income elasticity of the demand for exports is statistically significant at the $1 \%$ level, showing that a 1 percentage point increase in foreign income is responsible for a 3.458 percentage point increase in exports. This is a remarkable result for the Slovak economy, showing that exports are highly competitive in international markets in terms of the supply characteristics they possess, associated with quality aspects. The price elasticity of the demand for exports is not statistically significant, thus confirming the price pessimism hypothesis in international trade.

Consumption growth is income inelastic as expected by the standard consumption theory, and investment growth is income elastic, confirming the well-known accelerator theory. This shows that consumption grows at a lower rate than disposable income, but investment grows 2.6 percentage points for every 1 percentage point increase in real domestic income. Therefore, the accelerator impact is dominant in the investment equation, showing that investment projects are undertaken only when perspectives on economic growth are fulfilled. An unexpected result is that investment is elastic with respect to changes in real interest rate, the elasticity carrying an unexpected positive sign, but it is only statistically significant at the $10 \%$ level.

We also regressed each of the equations individually by 2SLS (see Table B.2 in Appendix B) using the same set of instruments. The intention was to carry out a few diagnostic tests to justify the robustness of our results. The first is the Sargan test, used for testing over-identifying restrictions, to check the validity of the instruments used in the regressions; this hypothesis is 
confirmed in all cases. The second is the Pagan-Hall heteroskedasticity test, showing that the hypothesis of homoskedasticity is never rejected. The third test is the Cumby-Huizinga test for autocorrelation, confirming that errors are not first-order autocorrelated in all cases. Finally, the normality hypothesis of residuals is also confirmed in all equations.

\section{Testing the model for the Slovak economy}

Table I, below, reports all the values necessary to compute the growth of domestic income in Slovakia given by Equation (9). Some values represent the elasticities obtained by estimating the structural equations of the model as explained in section 3, and the remaining figures represent annual averages of the respective components of Equation (9). If we insert all these values in Equation (9), the growth rate of domestic income in Slovakia can be obtained after controlling for internal and external imbalances and assuming changes in relative prices. The obtained growth is equivalent to $\dot{y}_{a}=1.983 \%$, which is lower than the actual growth achieved of $\dot{y}=3.96 \%$ over the whole period (see bottom of Table I). On the other hand, the average growth rate obtained by using the simple Thirlwall Law ${ }^{11} \dot{y}_{b}=3.289 \%$ is also less than the growth rate actually achieved in Slovakia. Two main remarks can be made at this point:

(i) Thirlwall's Law over-predicts the growth rate of Slovakia in comparison to our extended model. Therefore, if internal imbalances and relative price movements are ignored in Thirlwall's growth model, the predicted growth rate for the Slovak economy is overestimated.

Table I. Computation of the growth rates of domestic income. Slovakia, 1996-2015.

\footnotetext{
${ }^{11}$ To compute Thirlwall's Law given by $\dot{y}_{c}=\frac{\dot{x}}{\pi}$, it is necessary to estimate the import demand function $\dot{m}=\pi \dot{y}+\delta_{m}\left(\dot{p}^{*}+\dot{e}-\dot{p}\right)$ by 2SLS to obtain the aggregate income elasticity of the demand for imports, $\pi=2.598$. The growth rates of consumption, investment, exports and relative prices are used as instruments for $\dot{y}$, which is treated as endogenous in the import equation. The average growth rate of exports is 8.545 for the whole $1996-2015$ period considered.
} 


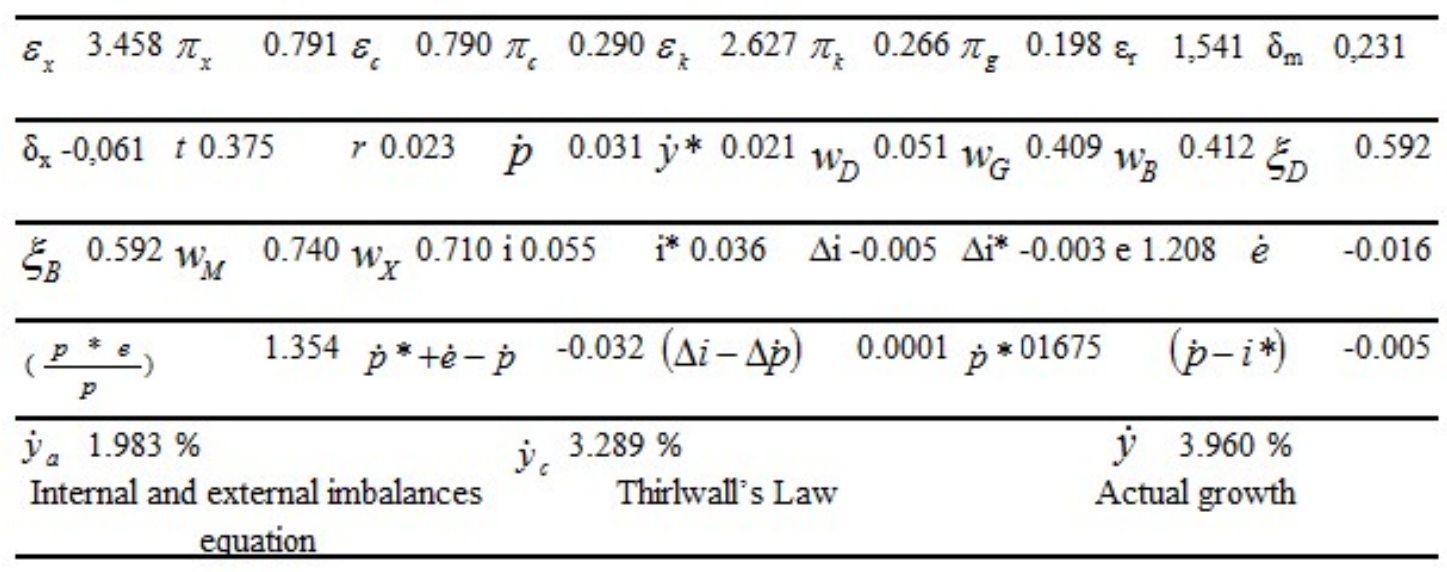

Notes: $\varepsilon_{x}, \pi_{x}, \varepsilon_{c}, \pi_{c}, \varepsilon_{k}, \pi_{k}, \pi_{g}, \varepsilon_{r}, \delta_{m}$ and $\delta_{x}$ are taken from Table B.1 (see Appendix B).

$r, t, w_{D}, w_{G}, w_{B}, w_{M}, w_{X}, i, i^{*}, e, \dot{p}$ and $\dot{y}^{*}$ are annual averages over the period of 1996-2015. $\xi_{D}$ and $\xi_{B}=0.625$, the percentage of public deficit (or debt) owned by national bond holders, is an average value over the whole period.

(ii) Both Thirlwall's Law and our extended model determine lower growth rates for the Slovak economy in comparison to the actual growth achieved for the whole period. According to the spirit of Thirlwall's Law, Slovakia managed to grow faster than the rate allowed by the balance of payments constraint, which should be consistent with the accumulation of current account deficits.

In fact, the current account deficit as a percentage of GDP shows an average annual ratio of 5.195\% for the whole 1996-2015 period. As shown in Chart 1 (Appendix C), the current account is always negative except for the years 2012, 2013 and 2015, where a trade surplus is recorded. Despite the average ratio being negative for the whole period, the current account deficit tends to be lower in more recent years and turns into a small surplus $(0.8 \%)$. This is an encouraging result, and according to Thirlwall's Law the Slovak economy is capable of growing faster without being constrained by the balance-of-payments if this positive tendency on the current account continues over the following years. This result is consistent with the relatively higher performance of exports $(8.55 \%$ average annual growth) in comparison to imports (7.87\%), as can be seen in Chart 2 (Appendix C). One also notices in Chart 3 that the Slovak economy grows faster on average than OECD countries (3.96\% versus $2.13 \%$ ), allowing it to catch-up with these countries, but at the cost of accumulating external imbalances. 


\section{A scenario analysis}

Using our extended model from Equation (9), a scenario analysis can be built aiming at detecting the factors that could improve or retard economic growth in Slovakia.

(i) Fiscal policy towards a friendlier taxation policy: if taxation on income falls from $t=37.5 \%$ (the prevailing average rate for the whole period) to $20 \%$ (everything else constant), the growth predicted by our extended model increases from $\dot{y}_{a}=1.983 \%$ to $2.15 \%$. Despite the positive effect on growth due to a friendlier taxation policy, the improvement in domestic income is not very substantial.

(ii) Budget policy towards equilibrium: Public deficit as a percentage of GDP in Slovakia shows an average ratio of $w_{D}=5.1 \%$ for the whole period, which is higher than the $3 \%$ established by the EMU and the Stability and Growth Pact. Policies aiming at reducing this ratio can positively affect economic growth in Slovakia. In fact, if public deficit reduces to $3 \%$, the growth rate in Slovakia increases from $\dot{y}_{a}=1.983 \%$ to $1.99 \%$ and a further reduction to $1 \%$ leads to a $2 \%$ growth rate in domestic income, respectively. Despite the positive effect on growth resulting from the deficit ratio reduction, the increase in domestic income growth is not very significant. Public debt (as a percentage of GDP) for the whole period shows an average ratio of $\mathrm{w}_{B}=41.2 \%$, which is lower than the $60 \%$ required by the EMU. However, if public debt increases to this ratio, the obtained growth of domestic income in Slovakia is almost the same as the prevailing one (1.976\%). Although higher growth is obtained with lower public deficit and debt, the improvement in income growth is not very sizeable.

The fact that the Slovak economy still shows a low public debt to GDP ratio may be explained by the revenues coming from the privatization process, which is not a sustainable solution for the near future, as this process will come to an end. We must consider that the high deficit ratio can be translated into higher debt in the future, and in the absence of 
privatization revenues, the economy could face difficulties in financing the accumulated debt.

In addition, the evidence from our model that changes in budget deficit and public debt do not have a sizeable impact on income growth should not be viewed as surprising. In the literature, a number of studies have concluded that variations in the public debt ratio have no significant effect on growth, such as Panizza and Presbitero (2014), Kourtellos et al. (2013) and Lof and Malinen(2014). Other studies found that the relation between debt ratio and income growth is non-linear and that there is a threshold rate between $70 \%$ and $90 \%$, above which the impact of the debt ratio on income growth becomes negative (e.g., Reinhardt and Rogoff, 2010; Cechetti et al. 2011; Checherita-Westphal and Rother, 2012; Baum et al. 2013; and Afonso and Jalles, 2013). A positive significant impact is only found at lower levels of the debt ratio.

Bearing this in mind, and considering that the average debt ratio for Slovakia is $41.2 \%$ in the period studied (well below the lower levels for which a positive significant impact on income growth is expected), and our scenario analysis assumes an increase to $60 \%$, these values should be found in the flat zone of the nonlinear relationship. Therefore, the small positive effect found in this study is consistent with other evidence in the relevant literature.

(iii) Reducing financial cost: It can be shown that growth in Slovakia is more sensitive to changes in foreign interest rates than to domestic ones. In fact, by reducing the foreign interest rate by only 1 percentage point from $i^{*}=3.6 \%$ (the prevailing average rate for the whole period) to $2.6 \%$, the growth rate predicted by our model shifts from $\dot{y}_{a}=1.983 \%$ to $2 \%$, a small increase. On the other hand, with a reduction of 2 percentage points in the prevailing domestic interest rate, from $i=5.5$ to $3.5 \%$, domestic income growth remains almost the same, $1.979 \%$. 
A combination of a $3 \%$ public deficit ratio (the EMU goal) and a $2 \%$ foreign interest rate results in $2.01 \%$ higher growth, in comparison to the prevailing average for the whole period $\dot{y}_{a}=1.983 \%$. Therefore, efforts to reduce the budget deficit combined with lower costs in financing the economy and its debt are favorable conditions for achieving higher growth in Slovakia.

(iv)Relative prices neutral: Contrary to the original Thirlwall's Law, our extended growth model assumes that relative prices are not neutral and that they affect the pace of economic growth. If we assume that relative prices are constant in the long-run, that is, $\dot{p}^{*}+\dot{e}-\dot{p}=0$, and therefore $\left(P^{*} e / P\right)=1, e=1$ and $\dot{e}=0$, and substitute these values into Equation (9), the obtained growth rate is $2.33 \%$, higher than that found when relative prices are not neutral, $\dot{y}_{a}=1.983 \%$ (see Table I). Therefore, relative prices make a substantial difference in the growth process, and when they are neglected, the model over-predicts the growth rate in Slovakia. On the other hand, it shows that the Slovak economy can grow faster in a system with price and exchange rate stability, which are in fact some of the main EMU goals.

(iv) External equilibrium and constant relative prices: An alternative scenario could be to predict the growth rate in Slovakia assuming that trade is balanced and that relative prices remain constant in the long-run. More specifically, the following conditions are imposed: export share equal to import share, $w_{M}=w_{X}=0.74$, and therefore, $w_{M} / w_{X}=1$; constant relative prices, $\dot{p}^{*}+\dot{e}-\dot{p}=0$, thus $\left(P^{*} e / P\right)=1, \quad e=1$ and $\dot{e}=0$. Substituting these values in Equation (9), the obtained growth rate is around $2.71 \%$, which is higher than the prevailing rate for the whole period $\dot{y}_{a}=1.983 \%$. Therefore, higher competitiveness and stable price and exchange rate conditions are beneficial for achieving higher growth in Slovakia. 
(v) Reducing the import sensitivity of exports: Table B.1 (Appendix B) shows that the elasticity of imports with respect to exports $\pi_{X}=0.791$ is quite high, although less than unity. This means that exports have a high dependence on imports, which is not a favorable result from the perspective of balance of payments. Therefore, developing policies with the aim of reducing the dependence of exports on imports should benefit domestic growth. For instance, by reducing the elasticity of imports with respect to exports from $\pi_{X}=0.791$ to 0.50 , the predicted growth of domestic income shifts from $\dot{y}_{a}=1.983 \%$ to $3.98 \%$, a substantial increase. Therefore, creating incentives for exporters to use domestic inputs is a proper policy that can foster domestic growth.

(vi) External balance and less dependence of exports on imports: the actual share of imports, $w_{M}=0.74$, is slightly higher than the share of exports, $w_{X}=0.71$, which indicates a trade deficit (on current account) over the whole period. Increasing the share of exports to the level of imports $\left(w_{X}=w_{M}=0.74\right)$, the growth rate predicted by our model increases significantly from $\dot{y}_{a}=1.983 \%$ to $2.27 \%$. If at the same time the sensitivity of exports with respect to imports reduces from $\pi_{X}=0.791$ (the actual rate) to $\pi_{X}=0.50$, the growth rate of domestic income increases even further, to around $4.27 \%$. Assuming a trade surplus, for instance $w_{M}=0.74$ and $w_{X}=0.80$, and maintaining $\pi_{X}=0.50$, the growth rate obtained is even higher, around $4.86 \%$. Therefore, developing trade policies with the aim of increasing export competitiveness and reducing export dependence on imports is a successful alternative to stimulate higher growth in Slovakia.

Scenarios (iii) to (vi) refer, in one form or another, to external balances. The claim that reduced external debt has a positive impact on growth is supported in the literature through two main channels: capital-accumulation and factor productivity growth. According to the first, investors will expect either higher taxes in the future to repay the public external debt or anticipate a financial crisis that could reduce expected future profits. As for the productivity growth channel, policy makers may be less willing to undertake difficult and 
costly policy reforms, as the benefits will be channeled to the exterior, and investors will pursue short-rather than long-term investment plans due to the perceived instability. The short-term perspective of investment plans may not favor the productivity growth associated with technical progress and innovation.

Empirically, Catão and Millesi-Ferreti (2015) found that, everything else constant, net external liabilities above $35 \%$ of GDP are associated with a steeper increase of financial crisis, and therefore increase economic uncertainty. Also, Pattillo et al. (2004) found that all these effects are in fact operating in a non-linear manner: for low levels of external debt the impact is not significant, but as the ratio increases, the relation becomes negative and significant.

As seen in the scenarios analysis, the most successful policies for achieving higher growth in Slovakia are related to the external sector, namely by making the economy more competitive, changing the import and export structure toward a trade balance or reducing the export dependence on imports. Price and exchange rate stability are also important conditions for higher growth, as they create less uncertainty in the economy. All the above remarks are in line with Thirlwall's Law and the balance of payments constraint hypothesis.

\section{Summary and concluding remarks}

In this paper, we use an extended growth model in line with Thirlwall's Law to predict the growth rate of the Slovak economy over the $1996-2015$ period. Slovakia is an interesting case study for two main reasons: the country belongs to the group of so-called transition economies, having peacefully separated from the former Czechoslovakia in 1993; and it has been one of the faster growing countries in Eastern Europe since its independence. The extended model we employ is different from that suggested by Thirlwall's Law in the sense that it controls for internal and external imbalances (the twin deficit hypothesis) and considers relative prices to be 
non-neutral in the process of economic growth. After defining the structural equations of the model, the reduced form of the domestic income growth rate is obtained, which, among other factors, depends on the structure of trade, fiscal imbalances, relative price movements, costs of financing the economy and other external factors such as the external demand and acquisition of public assets from abroad. The structural equations are estimated by 3SLS, being the most efficient technique to capture the interrelations and feedback effects of the model's core variables, and the estimation results are shown to be quite satisfactory despite the short period considered.

After carrying out all the necessary calculations, the predicted growth rate of the Slovak economy for the 1996-2015 period is computed, being lower than the rate actually observed. Therefore, the Slovak economy grew at a faster rate than that allowed by the balance of payments constraint hypothesis and this has been done at the cost of accumulating current account deficits. According to Thirlwall's Law, the country faces the risk of falling into the balance of payments constraint hypothesis in the long-run, unless capital flows can finance the current account imbalances, which is neither a sustainable nor a structural solution. Some encouraging results drawn from the current account tendency to show a surplus and a positive evolution of exports can eliminate the risk of entering a balance of payments crisis in the immediate future.

The scenarios analysis based on the extended growth model attempts to identify factors and, therefore, policies that could allow the country to achieve higher growth, thereby catching up with advanced European partners. It is shown that the most effective policy to achieve such a goal is found in the external trade sector, by making the economy more competitive. Changing the trade structure towards equilibrium and reducing the dependence of exports on imports are the most successful policies to achieving higher growth. One policy to achieve such an objective, and in line with Cimoli et al., (2010), is to implement measures that give priority to the high technology sectors and specialize in producing goods with high demand elasticity in 
international markets. Producing goods with high technological content is the way to increase export competitiveness while at the same time reducing import content.

Price and exchange rate stability are also beneficial to growth by creating economic conditions with less uncertainty. Financing the domestic economy and debt at lower cost and a friendlier taxation policy are also advantageous for higher growth, but to a lesser extent. A final concern is that of the high deficit ratio, which in the long-run would imply higher public debt, creating difficult conditions for financing these liabilities from abroad. The recent debt crisis of the peripheral euro zone countries provides an example of the loss of sovereignty that can occur in cases of unsustainable internal imbalances. 
- $\dot{m}_{t}$ - annual growth rate of real imports - Imports of goods and services at 2010 prices (national currency; annual percentage change).

- $\dot{c}_{t}$ - annual growth rate of final private consumption - Private final consumption expenditure at 2010 prices (national currency; annual percentage change).

- $\quad \dot{x}_{t}$ - annual growth rate of real exports - Exports of goods and services at 2010 prices (national currency; annual percentage change).

- $i \dot{n} v_{t}$ - annual growth rate of investment - Gross fixed capital formation at 2010 prices (national currency; annual percentage change).

- $\quad \dot{y}_{t}$ - annual growth rate of real GDP - GDP at 2010 market prices (national currency; annual percentage change).

- $\quad \dot{p}_{t}-$ annual growth rate of price deflator GDP at market prices (national currency; annual percentage change).

- $\quad \dot{p}_{t}^{*}$ annual growth rate of price deflator GDP at market prices, for the EU-12 (national currency; annual percentage change).

- $w_{G}$ - government expenditure as a share of GDP - Total expenditure; general government minus interest including flows on swaps and FRAs (\% of GDP at market prices; excessive deficit procedure).

- $w_{D^{-}}$government deficit as a share of GDP - Net lending (-) or net borrowing $(+)$; general government (\% of GDP at market prices; excessive deficit procedure).

- $w_{B}$ - government debt as a share of GDP - General government-consolidated gross debt (\% of GDP at market prices; excessive deficit procedure).

- $w_{M}$ - imports of goods and services at current prices (national accounts) - \% of GDP at market prices

- $w_{X^{-}}$. exports of goods and services at current prices (national accounts) - \% of GDP at market prices.

- $t$ - government revenues as a share of GDP - Total current revenue; general government $(\%$ of GDP at market prices; excessive deficit procedure).

- $\quad i$ - nominal long-term interest rates $(\%)$

1996-1999: annual average of the monthly discount rates of the National Bank of Slovakia 2000-2015: nominal long-term interest rates from the European Commission (2016).

- $i^{*}$ - nominal long-term interest rates $(\%)$ for Germany 
Data on $\dot{m}_{t}, \dot{c}_{t}, \dot{x}_{t}, i \dot{i n} v_{t}, \dot{y}_{t}, \dot{p}_{t}, \dot{p}_{t}^{*}, w_{G}, w_{D}, w_{B}, w_{M}, w_{X}, t$, and $i *$ were taken from European Commission (2016). Data on $i$ were provided by the National Bank of Slovakia (1996-1999) and European Commission (2016) for the period 2000-2015.

- $\quad \dot{g}_{t}-$ annual growth rate of primary government expenditure. Computed by the authors from data on "General government expenditure (Millions of euro)" from Eurostat (extracted on $9^{\text {th }}$ November 2016) and information on $\dot{p}_{t}$.

- $\quad \dot{y}^{*}$ - annual growth rate of foreign income (OECD), from OECD. Stat Extracts (extracted on $9^{\text {th }}$ November 2016), http://stats.oecd.org/

- $\quad \dot{y}_{d}-$ annual growth rate of real disposable income. Computed by the authors as the difference between the nominal annual growth rate of disposable income and the growth of prices. The nominal disposable income was computed from "Disposable income, million $€$, current prices" (Statistical Office of the Slovak Republic, National Bank of Slovakia) and the annual growth rate of prices, from "Price deflator private final consumption expenditure (national currency; annual percentage change)" (European, Commission, 2016).

- $e$-nominal effective exchange rate - price of domestic currency in terms of foreign currency - index $(2010=100)$ broad indices (61 countries). Computed by the authors using monthly data, from the Bank for International Settlements (BIS)- http://www.bis.org/statistics/eer/index.htm .

- $\left(P^{*} e / P\right)$ - real effective exchange rate index $(2010=100)$, broad indices (61 countries). Computed by the authors using monthly data, from the Bank for International Settlements(BIS)http://www.bis.org/statistics/eer/index.htm

- $\xi$ - the percentage of public deficit (or debt) owned by national bond holders was obtained from the Ministry of Finance of the Slovak Republic 


\section{Appendix B}

Table B.1. The 3SLS estimation of the structural model, 1996-2015.

\begin{tabular}{|c|c|c|c|c|c|c|c|}
\hline & Coefficient & Std Error & t-stat & p-value & $\mathbf{R}^{2}$ & F-stat & p-value \\
\hline \multicolumn{8}{|l|}{ Imports growth } \\
\hline constant & -1.980 & 1.611 & -1.23 & 0.224 & \multirow{6}{*}{0.858} & \multirow{6}{*}{25.89} & \multirow{6}{*}{0.000} \\
\hline$\dot{c}_{t}$ & 0.290 & 0.416 & 0.70 & 0.489 & & & \\
\hline$\dot{g}_{t}$ & 0.198 & 0.098 & 2.01 & $0.048 * *$ & & & \\
\hline$\dot{x}_{t}$ & 0.791 & 0.103 & 7.70 & $0.000 * * *$ & & & \\
\hline$i \dot{n} v$ & 0.265 & 0.123 & 2.17 & $0.034 * *$ & & & \\
\hline$\left(\dot{p}_{t}^{*}+\dot{e}_{t}-\dot{p}_{t}\right.$ & t) 0.231 & 0.248 & 0.93 & 0.355 & & & \\
\hline \multicolumn{8}{|c|}{ Consumption growth } \\
\hline constant & 0.735 & 0.504 & 1.46 & 0.150 & \multirow{2}{*}{0.755} & \multirow{2}{*}{67.03} & \multirow{2}{*}{0.000} \\
\hline$\dot{y}_{d, t}$ & 0.790 & 0.097 & 8.19 & $0.000 * * *$ & & & \\
\hline \multicolumn{8}{|c|}{ Investment growth } \\
\hline constant & -6.886 & 2.333 & -2.95 & $0.004^{* *}$ & \multirow{3}{*}{0.629} & \multirow{3}{*}{19.3} & \multirow{3}{*}{0.000} \\
\hline$\dot{y} t$ & 2.627 & 0.442 & 5.94 & $0.000 * * *$ & & & \\
\hline$r^{*} t$ & 1.541 & 0.852 & 1.81 & $0.075 *$ & & & \\
\hline \multicolumn{8}{|c|}{ Exports growth } \\
\hline constant & 1.051 & 2.808 & 0.37 & 0.709 & \multirow{3}{*}{0.434} & \multirow{3}{*}{7.66} & \multirow{3}{*}{0.001} \\
\hline$\dot{y}_{t}^{*}$ & 3.458 & 0.886 & 3.9 & $0.000 * * *$ & & & \\
\hline$\left(\dot{p}_{t}{ }^{*}+\dot{e}_{t}-\dot{p}_{t}\right.$ & t) -0.061 & 0.349 & -0.17 & 0.862 & & & \\
\hline
\end{tabular}

Notes to the table: Endogenous variables: $\dot{m}_{t}, \dot{c}_{t}, l \dot{n v} v, \dot{x}_{t}, \dot{g}_{t}, \dot{y}_{t}, \quad ., \dot{y}_{d^{\prime}, t},\left(\dot{r}_{t} *+\dot{e}_{t}-\dot{p}_{t}\right)$

Exogenous variables: $\dot{y}_{t}^{*}, \dot{y}_{t-1}{ }^{*}, t_{t}, i_{t}, i_{t-1}, i_{t-1}^{*}, \dot{p}_{t}^{*}, w_{B, t}, w_{D, t}, w_{G, t}, \dot{x}_{t-2}, \dot{k}_{t-2}$

$*, * *,{ }^{* *}$ Coefficient significant at the $10 \%, 5 \%$ and $1 \%$ level, respectively. 
Table B.2. The 2SLS estimation of each equation of the structural model, 1996-2015.

\begin{tabular}{|c|c|c|c|c|c|c|c|c|}
\hline & Coefficient & Std Error & t-stat & p-value & $\begin{array}{l}\text { Sargan } \\
\text { test }\end{array}$ & $\begin{array}{c}\text { Heteroscedasticity } \\
\text { test }\end{array}$ & $\operatorname{AR}(1)$ test & Normality test \\
\hline \multicolumn{9}{|l|}{ Imports growth } \\
\hline constant & -1.005 & 1.996 & -0.50 & 0.623 & $\chi_{7}^{2}=8.403$ & $\chi_{12}^{2}=8.046$ & $\chi^{2}{ }_{1}=0.006$ & $X_{2}^{2}=3.03$ \\
\hline$\dot{c}_{t}$ & 0.144 & 0.528 & 0.27 & 0.789 & p-value $=0.298$ & p-value $=0.782$ & $p$-value $=0.939$ & $\mathrm{p}$-value $=0.220$ \\
\hline$\dot{g}_{t}$ & 0.162 & 0.125 & 1.29 & 0.218 & & & & \\
\hline & 0.738 & 0.128 & 5.76 & $0.000 * * *$ & & & & \\
\hline$i n v$ & 0.361 & 0.156 & 2.32 & $0.038 * *$ & & & & \\
\hline$\left(\dot{p}_{t}^{*}+\dot{e}_{t}-\dot{p}_{t}\right)$ & 0.232 & 0.316 & 0.74 & 0.475 & & & & \\
\hline \multicolumn{9}{|c|}{ Consumption growth } \\
\hline constant & 0.846 & 0.543 & 1.56 & 0.138 & $\chi_{11}^{2}=16.594$ & $\chi_{12}^{2}=5.309$ & $X^{2}{ }_{1}=0.411$ & $X_{2}^{2}=1.66$ \\
\hline$\dot{y}_{d, t}$ & 0.760 & 0.106 & 7.16 & $0.000 * * *$ & p-value $=0.121$ & $\mathrm{p}$-value $=0.947$ & p-value $=0.521$ & p-value $=0.437$ \\
\hline \multicolumn{9}{|l|}{ Investment growth } \\
\hline constant & -5.935 & 2.580 & -2.30 & $0.035 * *$ & $X_{10}^{2}=15.258$ & $\chi_{12}^{2}=9.767$ & $x_{1}^{2}=0.464$ & $X_{2}^{2}=0.04$ \\
\hline$\dot{y} \quad t$ & 2.380 & 0.494 & 4.82 & $0.000^{* * *}$ & $\mathrm{p}$-value $=0.123$ & $p$-value $=0.636$ & $p$-value $=0.496$ & p-value $=0.981$ \\
\hline$r^{*} t_{t}$ & 1.959 & 0.976 & 2.01 & $0.062^{*}$ & & & & \\
\hline \multicolumn{9}{|l|}{ Exports growth } \\
\hline constant & -0.337 & 3.168 & -0.11 & 0.917 & $X_{10}^{2}=15.812$ & $\chi_{12}^{2}=6.707$ & $\chi_{1}^{2}=1.639$ & $\chi_{2}^{2}=2.00$ \\
\hline$\dot{y}_{t}^{*}$ & 3.648 & 1.014 & 3.60 & $0.002 * * *$ & $p$-value $=0.105$ & $p$-value $=0.876$ & $p$-value $=0.200$ & $p$-value $=0.368$ \\
\hline$\left(\dot{p}_{t}^{*}+\dot{e}_{t}-\dot{p}_{t}\right)$ & -0.339 & 0.406 & -0.83 & 0.416 & & & & \\
\hline
\end{tabular}

Notes to the table: Endogenous variables: $\dot{m}_{t}, \dot{c}_{t}, l \dot{n} v, \dot{x}_{t}, \dot{g}_{t}, \dot{y}_{t}, \quad, \dot{y}_{l i,{ }_{l},}\left(\dot{r}_{t}{ }^{*}+\dot{e}_{t}-\dot{p}_{t}\right)$

Exogenous variables: $\dot{y}_{t}^{*}, \dot{y}_{t-1}{ }^{*}, t_{t}, i_{t}, i_{t-1}, i_{t-1}^{*}, \dot{p}_{t}^{*}, w_{B, t}, w_{D, t}, w_{G, t}, \dot{x}_{t-2}, \dot{k}_{t-2}$

$*, * *, * * *$ Coefficient significant at the $10 \%, 5 \%$ and $1 \%$ level, respectively. 


\section{Appendix C}

Chart 1. Current account balance (cagdp) as a percentage of GDP, 1996-2015

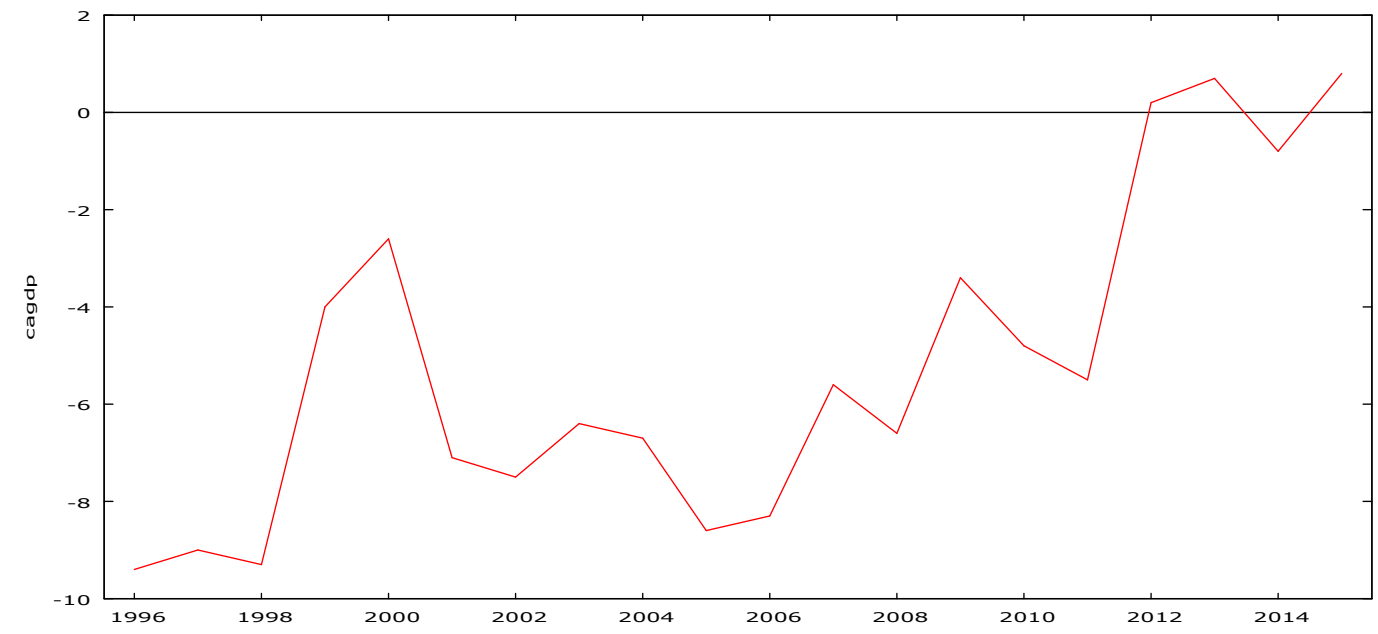

Chart 2. Annual growth rate of exports (gx) and imports (gm), 1996-2015

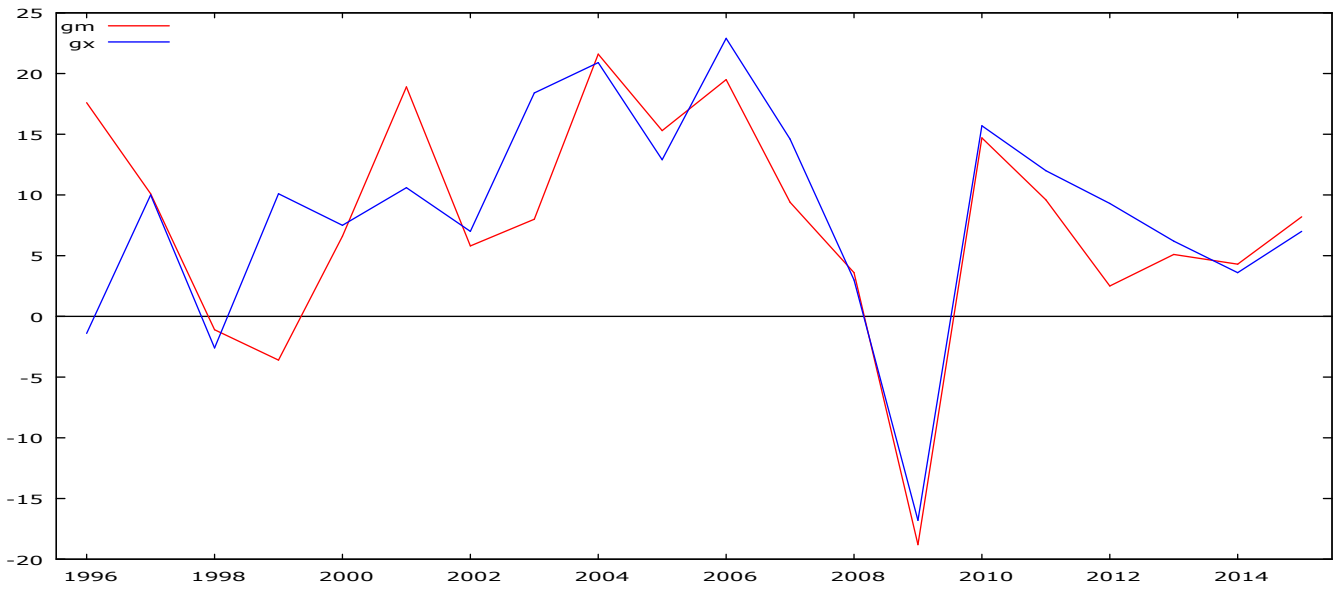

Chart 3. Annual growth rate of domestic (gy) and foreign income (goecd), 1996-2015

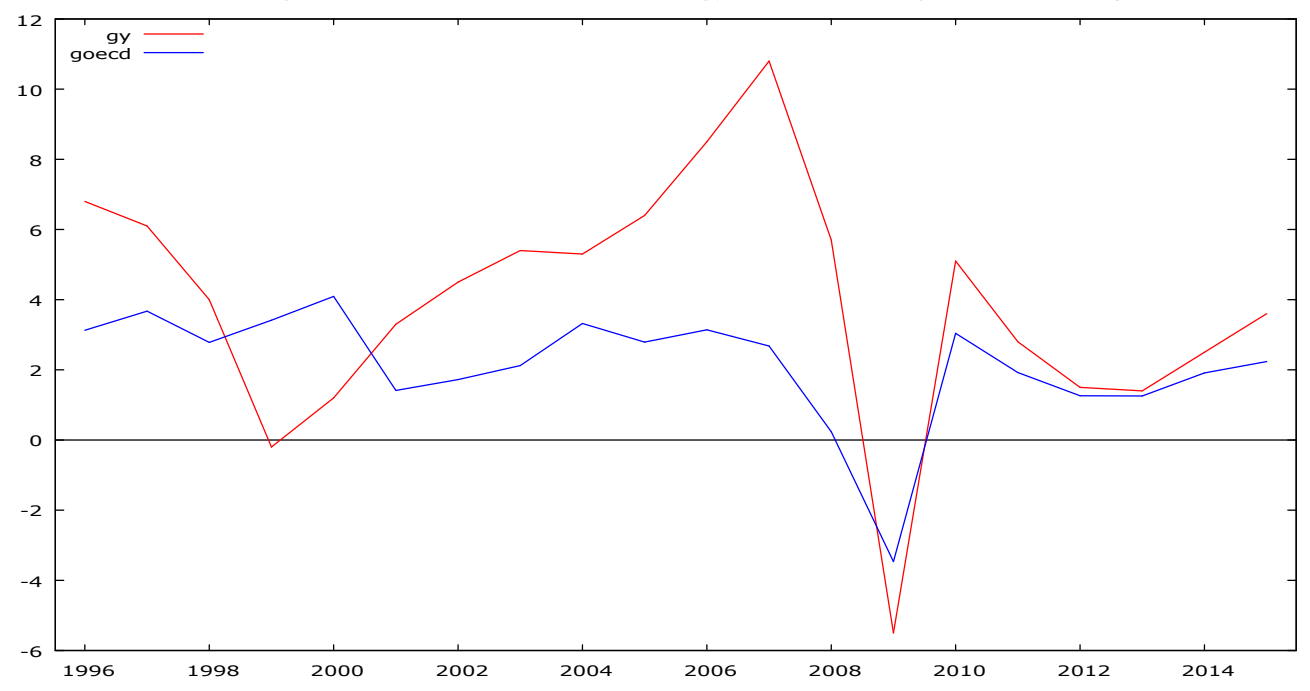

Source: Authors' computation using data from the European Commission (2016) 


\section{References:}

Afonso, A., andJ. T. Jalles (2013). "Growth and productivity: The role of government debt”. International Review of Economics \& Finance, 25, 384-407.

Alonso, J., and C. Garcimartín (1998-99). "A new approach to balance-of-payments constraint: some empirical evidence." Journal of Post Keynesian Economics, Winter, 21(2), 259-282.

Baum, A., Checherita-Westphal, C., and P. Rother (2013). "Debt and growth: New evidence for the euro area". Journal of International Money and Finance, 32, 809-821.

Blecker, R. (2009). "Long-run growth in open economies: export-led cumulative causation or a balance-of-payments constraint?" Paper presented at the 2nd Summer School on Keynesian Macroeconomics and European Economic Policies, 2nd-9th August, Berlin, Germany.

Catão, L. A., and G. M. Milesi-Ferretti (2014). "External liabilities and crises". Journal of International Economics, 94(1), 18-32.

Checherita-Westphal, C., and P. Rother (2012). "The impact of high government debt on economic growth and its channels: An empirical investigation for the euro area”. European Economic Review, 56(7), 1392-1405.

Chenery H. B. (1952). "Overcapacity and the Acceleration Principle." Econometrica, 20, 1-28.

Cimoli, M., G. Porcile and S. Rovira. (2010). "Structural change and the BOPconstraint: why did Latin America fail to converge?"Cambridge Journal of Economics, Vol. 34, No. 2 389-411

European Commission (2016). "Statistical Annex of European Economy." Directorate General Economic and Financial Affairs, Spring.

Garcimartín, C., Rivas, L., and P. Martínez (2010-11). "On the role of relative prices and capital flows in balance-of-payments constrained growth: the experiences of Portugal and Spain in the Euro Area." Journal of Post-Keynesian Economics. Winter, 33 (2), 281-306.

Goodwin R.M. (1951). "The Non-linear Accelerator and the Persistence of Business Cycles." Econometrica, 19(1), 1-17.

Kourtellos, A., Stengos, T., and C. M. Tan (2013). "The effect of public debt on growth in multiple regimes". Journal of Macroeconomics, 38, 35-43.

Lof, M., and T. Malinen(2014). "Does sovereign debt weaken economic growth? A panel VAR analysis". Economics Letters, 122(3), 403-407.

López, J., and A. Cruz (2000). "Thirlwall's law and beyond: the Latin American experience." Journal of Post Keynesian Economics, spring, 22(3), 477-95. 
McCombie, J. (1989). "Thirlwall's Law and balance-of-payments constrained growth a comment on the debate." Applied Economics, 21, 611-629.

McCombie, J., and A. Thirlwall (1994). "Economic growth and the balance-ofpayments constraint." MacMillan Press, Basingstoke; St. Martin's Press, New York.

McGregor, P., and J. Swales (1985). "Professor Thirlwall and the balance-of-payments constrained growth.” Applied Economics, 17, 17-32.

McGregor, P., and J., Swales (1991). "Thirlwall's Law and balance-of-payments constrained growth: further comment on the debate." Applied Economics, 23, 9-23.

Moreno-Brid, J. (1998-99). "On capital flows and the balance-of-payments-constrained growth model." Journal of Post Keynesian Economics. Winter, 21(2), 283-298.

Panizza, U., and A. F. Presbitero(2014). "Public debt and economic growth: is there a causal effect?". Journal of Macroeconomics, 41, 21-41.

Pattillo, C. A., Poirson, H., and L. A. Ricci(2004). "What Are the Channels Through Which External Debt Affects Growth?”. IMF WP 04/15.

Pelagidis, T., and E. Desli (2004). "Deficits, growth, and the current slowdown: what role for fiscal policy?" Journal of Post Keynesian Economics, 26(3), 457-465.

Reinhart, C. M., and K. S. Rogoff (2010). "Growth in a time of debt". American Economic Review, 100(2), 573-578.

Soukiazis E., and P. A. Cerqueira (2012). "Models of Balance of Payments Constrained Growth. History, Theory and Empirical Evidence", Palgrave-Macmillan.

Soukiazis E., Cerqueira, P., and M. Antunes (2012). "Growth rates constrained by internal and external imbalances and the role of relative prices: empirical evidence from Portugal"Working Paper n ${ }^{\circ} 8$, GEMF, http://gemf.fe.uc.pt

Soukiazis E., Cerqueira, P., and M. Antunes (2013-14). "Growth rates constrained by internal and external imbalances and the role of relative prices: empirical evidence from Portugal", Journal of Post Keynesian Economics, winter, vol.36, №2, 275-298.

Soukiazis E., Muchova, E. and J. Lisy, (2013). "Slovak economic growth and the consistency of the balance-of-payments constraint approach",Journal of Economics/Ekonomický časopis, vol. 61, Nº.9, 879-896.

Thirlwall, A. (1979). "The balance-of-payments constraint as an explanation of international growth rate differences." Banca Nazionale del Lavoro, 128, 45-53. 
Acknowledgment: The paper was elaborated with the support of the project VEGA no.1/0393/16. 